\title{
Socio-Economic Impacts of Wildlife Tourism in Kasara, Chitwan ${ }^{1}$
}

\author{
Janak Puri \\ Deputy Superintendent of APF, Nepal \\ Student Officer, $3^{\text {rd }}$ APF Command and Staff Course \\ Email: purijanak333@yahoo.com
}

\begin{abstract}
Tourism is considered as one of the largest and fastest developing sectors of the world. Its high growth and development rates bring considerable volumes of foreign currency inflows, infrastructure development, employment generation, regional development, economic multiplier effects and introduction between host and guest peoples experience actively affect various sectors of society, which can positively affected to the social and economic development. However the tourism also generates a number of other negative socio-economic impacts on local communities. This study considers the mainly socio-economic impacts on local community trough tourism development in Kasara. The study is focused to identify the social and economic impacts on local community and their perception towards the tourism. The study is adapted the qualitative methodology and the data is generated through primary and secondary source, personal interviews, discussions and social interaction. The study identified that community has developed positive attitudes about the tourism development and the community is accepted tourism as a major income source through active and passive participations. As usually the tourism has generated both positive and negative impacts in the society. However, the negative impacts are at a minimum level when compare with the positive impacts. The social tradition, culture and human behaviour exchange between host guest interactions. The tourism revitalizes the culture and sometime declines the culture of the host country. The tourism helps to develop the livelihood of the people and can earn money from the different business and cultural activities. Community empowerment and their capacity building are highly important in this context.
\end{abstract}

Key Words: Tourism, socio-economic impacts, economy, wildlife, livelihood

\section{Introduction}

The name Chitwan is a composite of the Sanskrit words "Chitta", transliterated "Citta" meaning heart and "Ban", transliterated "Vana" meaning jungle or forest. Thus, the meaning of Chitwan is Heart of the Jungle. Chitwan was a dense forest ruled by the Tharu God/King Chitrasen Baba. "People believe him as the incarnation of Lord Vishnu. Still today, Tharu people worship their idol during HariBodhini Ekadashi in Chitrasari (Headquarters of Chitrasen Baba), way to Sauraha" Chitwan (Chitwan, 2013a).

The Chitwan district is located in the southwestern part of province no. three having with Bharatpur, the fourth largest city of Nepal, as its district headquarters. "It covers an area of 2,238.39 km2 $(864.25 \mathrm{sq}$ $\mathrm{mi})$, and in 2011 had a population of 579,984 (279,087 male and 300,897 female) people. Out of the total area of district, about $64 \%$ is covered by forest area, a major part of which is the Chitwan National Park and wildlife conservation area placed in the World Heritage Site" (Pedersen, 2002, p. 89).

Chitwan meets three criteria for the World Heritage natural properties, such as the last surviving example of the natural ecosystems of the Terai region, superlative natural features of exceptional natural beauty in terms of its scenic attractions of forested hills, grasslands, great rivers and views of the distant Himalayas and significant populations of several rare and endangered species, especially the one horned Asian rhinoceros and the Gharial crocodile (DNPWC, 2013).

In 1988, Smith stated many of the widely quoted definitions of the field come from the World Tourism Organization's (WTO) guidelines on statistical data collection standards. Among the words, they define "tourist" as:

Any person residing within a country, irrespective of nationality, travelling to a place within this country other than his usual place of residence for a period of not less than 24 hours or one night for a purpose other, than the exercise of a remunerated activity in the place visited. The motives for such travel may be (a) leisure (recreation, holidays, heath, studies, religion, sports); (b) business, family, mission, meeting (World tourism organization, 1981).

In 1936, the League of Nations defined a foreign tourist as "someone traveling abroad for at least twentyfour hours". Its successor, the United Nations, amended this definition in 1945, by including a maximum

\footnotetext{
${ }^{\mathbf{1}}$ This study paper is based on ongoing thesis and findings are based on currently collected primary and secondary data.
} 
stay of six months (Theobald, 2005). In 1941, Leiper defined tourism as "the sum of the phenomena and relationships arising from the travel and stay of non-residents, in so far as they do not lead to permanent residence and are not connected with any earning activity".

Wildlife tourism is an element of many nations' travel industry centered on observation and interaction with local animal and plant life in their natural habitats. Wildlife tourism, in its simplest sense, is interacting with wild animals in their natural habitat, either by actively (e.g. hunting/ collection) or passively (e.g. watching/photography). It has experienced a dramatic and rapid growth in recent years worldwide and many elements are closely aligned to sustainable tourism (Gautam, 2011).

Tourism focused principally on natural resources such as relatively undisturbed parks and natural areas, wetlands, wildlife reserves and other areas of protected flora, fauna and habitats (Laarman\& Durst, 1993; Weaver, 2006). Wildlife-watching tourism is a type of ecotourism that should be distinguished from other forms of wildlife tourism, such as captive-wildlife, hunting and fishing tourism (Higginbottom, 2004; Newsome, Dowling, \& Moore, 2004). Peter (1964) defined as relating to or concerned with the interaction of social and economic factors as:

The prefix socio- refers to "the study of the behaviors of people," including the ways they interact with one another or their family structures. The word economic refers to the economy, such as people's income and finances. Socioeconomic links financial and social issues together (Peters, 1964).

Wildlife tour is one of the best jungle safari tour not only in Nepal but also in Asia. Chitwan National Park is probably Asia's finest one which the first national park in Nepal. It was established in 1973 and granted the status of a World Heritage Site recognizing its unique biological resources in 1984 (CNP, 2013a). It covers an area of $932 \mathrm{~km}^{2}$ and is located in the subtropical inner Terai lowlands of southcentral Nepal and extends to Parsa, Chitwan and Makwanpur. Altitudinal variation ranges from about 100 $\mathrm{m}$ in the river valleys to $815 \mathrm{~m}$ in the Churia Hills (Pedersen, 2002). In early days before the national park establish the jungle was popular as hunting spot among Ranas and king/royal family.Lieper's definition, the most complex of these examples, states that tourism should be considered as:

... the system involving the discretionary travel and temporary stay of persons away from their usual place of residence for one or more nights, excepting tours made for the primary purpose of earning remuneration from points reroute. The elements of the system are tourists, generating regions, transit routes, destination regions, and a tourist industry. These five elements are arranged in spatial and functional connections. Having the characteristics of an open system, the organization of five elements operates within broader environments: physical, cultural, social, economic, political, technological with which it interacts (Leiper, 1979).

Lieper's expressed purpose for this definition is as ambitious as the definition is long. He hopes the definition will serve as a guide for "general tourism studies" and as a bridge between two academic camps, which he describes as being "the business enterprise and economic development camp" and the impact and externalities camp.

Tourism is considered as one of the largest and fastest developing sectors of the world and its high growth and development rates, considerable volumes of foreign currency inflows, infrastructure development, and introduction of new management and educational experience actively affect various sectors of economy, which is positively affect to the social and economic development of the country. Tourism provides about 10 percent of the world's income and employs almost one out of tenth of the world's workforce. Many people emphasize the positive aspects of tourism as a source of foreign exchange, a way to balance foreign trade, an "industry without chimney". But there are also a number of other positive and negative sides of tourism's economic impacts on local communities (Nayomi \& Gnanapala, 2015).

Tourism is one of the most important components of the global economy. It generates billions of dollars in revenues and millions of jobs worldwide(Paul, 2012). It is considered by many communities, especially in emerging countries the only tool for development, and the only chance for increasing the quality of life. Thus the tourism industry has stretched from seaside to mountain resorts and from small villages to big metropolises. But at the same time, tourism started to show its uglier side.

Wildlife-watching tourism is a type of ecotourism that should be distinguished from other forms of wildlife tourism, such as captive-wildlife, hunting and fishing tourism. From the socio-cultural perspective, tourism brings together people from different backgrounds, cultures and traditions. More than fifty five percent tourist visits Chitwan among tourist arrival in Nepal. The tourist focused Chitwan 


\section{2 | Journal of APF Command and Staff College}

to visit wildlife in Chitwan National Park (CNP, 2013a). People believe that tourism is a service industry that takes care of visitors when they are away from home. Some restrict the definition of tourism by number of miles away from home, overnight stays in paid accommodations, or travel for the purpose of pleasure or leisure (Wikramanayake, et al., 1999). Others think that travel and tourism should not even be referred to as an industry.

Chitwan National Park and the community forests provide shelter to several rare animals. Wildlife tourism in Chitwan is well-known as the inhabitant of one-horned rhinoceros. "Thousands of internal as well as international tourists visit the park as well as the community forests every year to view the animals and the resources like Tiger, Bison, Deer, Bear, Crocodile Breeding Center and the rare insects. Chitwan National Park, being the oldest national park in the country inhabiting a diverse biodiversity, broadens the scope of the wildlife tourism in the district and the country" (CNP, 2013a). Chitwan National Park has been attracting the tourists from around the world.

The park also provides the facilities of elephant safari so that the visitors can get a close view of the animals sitting on the elephants. After increment of hotels and lodges in Chitwan, slowly tourism industry started to get heads up. Basically the most relational sector to tourism industry is hotel industry. All the business holders started their business for improvement of their own and for increasing the number of tourists' visit. It is also argued that tourism should be seen as a means of development in a broader sense (Krapf, 1961; Kaiser \& Helber, 1978; Mathieson \& Wall, 1982; Murphy, 1985; Wahab \& Pigram, 1997). These analysts describe the broader sense of tourism to mean the potential of the industry to have direct socio-economic impacts on destination community after guest and host interaction.

To conceptualize the socio-cultural impact of tourism, first we need to understand the terms society and culture. Sociology is largely concerned with the study of society and focuses on people in groups and the interaction of those in groups, their attitudes and their behavior. Culture is a similar concept to society and is about how people interact as observed through social interaction, social relations and material artifacts. According to Burns and Holden (1995), when discussing culture within the context of tourism, they indicate that it consists of behavioural patterns, knowledge and values which have been acquired and transmitted through generations. Burns and Holden (1995) provide more detail when they indicate that "culture ...includes knowledge, belief, art, moral law, custom and any other capabilities and habits of people as members of society (p. 113)". Social and cultural impacts are the ways in which tourism is contributing to changes in the value systems, morals and their conduct, individual behaviour, family relationships, collective lifestyles, creative expressions, traditional ceremonies and community organization. It refers to the effects on the host community as a result of direct or indirect association with tourists in host community.

Tourism may have many different effects on the social and cultural aspects of life in a particular society, depending on the cultural and religious strengths of that region. The interaction between tourists and the host community can be one of the factors that may affect a community as tourist may not be sensitive to local customs, traditions and standards. The effect can be positive or negative on the host community. The socio-cultural impacts of tourism described here, are the effects on host communities of direct and indirect relations with tourists and of interaction with the tourism industry. For a variety of reasons, host communities often are the weaker party in interactions with their guests and service providers (Cook, 2011). The impacts arise when tourism brings about changes in value systems and behavior, thereby threatening indigenous identity. Furthermore, changes often occur in community structure, family relationships, collective traditional life styles, ceremonies and morality.

\section{Statement of the Problem}

Since the second half of the twentieth century, tourism has been gaining momentum and in 2011 total revenues from tourism activities have reaches 1000 billion dollars (UNWTO, 2012). So it can firmly say that tourism, compared to other industries, it has a superior capacity to distribute wealth and promote regional development; it has a high multiplier effect; it generates a varying consumption of goods and services. But a series of scholars and researchers have found a growing number of examples of negative impacts of tourism in the host regions. In the present paper, Paul (2012) trying to present a series of positive and negative impacts of tourism from two points of view: economic and socio-cultural. Hall (2000) stated that the main reason why governments, particularly in developing countries encourage tourism investment because of the expectations that it will contribute to economic development for 
country. In Chitwan, "There are one-star hotel one, twenty one two-star hotels, three star hotel sixty five, four star hotel three and five star hotel four" (Personal communication, 23 November 2018).

In this context study focused to the socio-economic impacts of wildlife tourism in Kasara. Because of its "rich wildlife diversity and scenic beauty, Chitwan National Park has attracted tourists from various countries" (Bhusal, 2007). The natures of tourism in destination areas make it have socio-economic impacts, an aspect that this study aims at addressing. The peoples reside in near hotel and surrounding areas of the Kasara also has been involved in tourism field in different ways. Some of them are selling their products and some of them are getting temporary job in this tourism sector. Peoples are engaging in the tourism but how they are benefitted or what kinds of impacts on host society are not researched. So study focused on how tourism contributes for people's livelihood and what are the impacts of tourism in neighboring society. The study focused on how wildlife tourism contributes for the livelihood of peoples, and what impacts of wildlife tourism in host society Kasara.

\section{Literature Review}

This study has emphasized that socio-economic impacts of tourism can be better understood at regional scale than at the local scale where tourism activities are really taking place. Tourism comprises the activities of persons travelling to and staying in places outside their usual environment for not more than one consecutive year for leisure, business and other purposes not related to the exercise of an activity remunerated from within the place visited (UNWTO, 2000). Tourism industry does not have a single entity but it is the combination of different sectors including primary suppliers like attraction of the destination, transportation industry (air and surface),hospitality industry (hotels, restaurant etc.), tour operators, travel agents, banking, insurance, shopping and entertainment. For instance, a hotel required supply of vegetables, fruit and other items in order to provide its services further, therefore fruits and vegetable suppliers are the secondary suppliers of the tourism industry as suppliers to primary suppliers (WTTC, 2012).

Bhattarai et al. (2005) described Chitwan National Park as a typical example of externally induced, uneven development rather than a model of wildlife conservation. Several authors argue that the endangered species in the park are indeed protected, but only to be commoditized for the consumption of high-class tourism (Bookbinder et al., 1998; Jones, 2007; Spiteri\& Nepal, 2008b). It is further argued that the park's establishment has severely disrupted the domestic economy of local people (Stræde \& Helles, 2000; McLean \& Straede, 2003; Hjortso et al., 2006). Tourism is now one of the world's major industries and is continuously expanding. It can be viewed in term of demand of the tourist and supply of the attractions, facilities and services, transportation, promotion and information. Market tends shows that tourists are becoming more activity oriented and environmentally conscious, and that tourist markets are increasingly fragmented (Kunwar, 2017, p.15).

In 1982, Mishra stated that the Chitwan National Park is a popular destination for overseas tourists visiting Nepal, whereas the Kasaraand Sauraha sector as the major destinations. Governmental controls on tourist concessionaires inside Chitwan national park and the small number of domestic elephants available for tourists have limited the impact of tourism on economic sector. In 2017, Kunwar stated in his book 'Tourist and Tourism' tourism hospitality as “... rather than assuming that hospitality entails a particular context (such as the home or hotel) or particular objects (such as food and beds) or particular actors (such as host and guests), ... hospitality as both a condition and an effect of social relations, spatial configurations and power structures" (Lynch, et al., 2011). To justify it they (Lynch, et al., 2011) further express that, hospitality is constructed by, also productive of certain contexts, spaces, politics, objects, social roles and relation.

The establishment and management of parks and protected areas are receiving increasing attention worldwide. Whether spurred by the realization that protected areas play a valuable role in maintaining biological diversity or by a desire to reap economic benefits from tourism and other direct uses, governments are analyzing the various alternative ways of establishing and managing these areas (Dixon \& Sherman, 1990). Managers of protected areas are generally confronted with a classic financial problem: they may be in charge of highly valued properties and yet not have the means to generate an income flow to sustain the assets. In the developing world, sustainable funding resources for conservation are scarce (Park, N. J. M. C., \& Bardecki, 2016). 


\section{4 | Journal of APF Command and Staff College}

Wildlife tourism can contribute enormously to the management of protected areas. Benefits include foreign exchange revenues, employment opportunities, improving awareness of conservation objectives and stimulation of economic activity. In addition, wildlife tourism is a major vehicle for realizing tangible benefits of conservation for local communities with wildlife populations occurring on their land. However, the benefits accruing to local communities from tourism have so far been overstated (Roe, 1997). Popular captive wildlife and ecotourism attractions are such as zoos and aquariums. Wildlife tourism can be understood as a form of tourism that is based on interactions between tourists and nondomesticated animals. Tourism is a major driver of economic growth (Frost, 2011; Grajal, 2013; Higginbottom, 2004) annually host approximately 700 million visitors worldwide (World Association of Zoos and Aquariums, 2016); are a major motivation for tourist visitation (Higginbottom, 2004); and are thus ideally placed to educate visitors about the need for animal and environmental conservation.

Tourist typology can be grouped in to general categories these are: a. interactional type and b. cognitivenormative models, which stress the motivations behind travels. According to the researcher Cohen (1972) developed four types of tourist these are namely Drifter, Explorer, Individual mass tourist and Organized mass tourist (Kunwar, 2002). Protected areas must be valued as areas where sustainable resources use and rural development can operate in partnership with a wide range of stakeholders (Wikramanayake, et al., 1999). It is important for successful management of protected areas to understand their economic value, but equally important to find ways of capturing that value (Roe, 2003). The difficulty in capturing value comes from protected areas having not only direct and commercial values but also indirect values, option values, existence values and non-use benefits (Cook, 2011).

The literature regarding wildlife tourism and its socio-economic impacts in Chitwan, there are little literature particularly related to topic but can find abundant amount of literature regarding other aspects tourism impacts. The socio-economic impacts of wildlife tourism are new and less focused in academia. Some practical paper, guideline, information are available which can be taken as source of knowledge for socio-economic impacts of wildlife tourism in Chitwan. Most of the available literatures are focused in Sauraha for wildlife tourism and its socio-economic impacts. Majority of literature are talking about the concept of wildlife tourism and people. A meta-analysis is typically a systematic review using statistical methods to effectively combine the data used on all selected studies to produce a more reliable result. Kasara based researches were not found in the subject 'tourism and its impacts on livelihood and host society'. Taking this entire factor in consideration, research focused on socio-economic impacts to the host society Kasara. Research concentrated especially in how tourism contributes the livelihood of the people and how tourism impacts to the society of the Kasara.

\section{Methodology}

The study is carried out in Kasara, which is famous tourism destination in Chitwan after Sauraha. Kasara is the headquarters of the Chitwan national park. The Chitwan national park, local community and surrounding areas/society are well covered for this study. Descriptive report, primary and secondary sources of information and internet are used for more relevancy. The sources of information were books, reports, articles, newspaper, websites and answer given by participant and other related to the topic are covered. Person working in the field of tourism and other stake holders has been consulted. The primary data collected through in-depth interview, focus group discussion, observation and participants' responses. Some of the data has been collected from government officials. According to Nachmias and Nachmias (2000), field research is a way of empathizing with and understanding the subjective meanings of the people and collects the subjectivity of research participants.

The study is targeted to the hotels, tourism business, and the local community of Kasara. At present there are 9 hotels in Kasara and managers are working in the different hotels and about 282 families are living in the Kasara village. For convenience of study, random selected 30 families and 9executive managers of hotel for the data collection through personal interview and discussion. Questions administered to safari operators and home-stay operators, house makers and the head of the family and tourism-related businesses and representatives of the Kasara, ward no 23 of Bharatpur metropolitan city. Although random sampling technique has been adopted, representation from all groups has been well covered. Variation of age, occupation, ethnicity, education has been covered in research and authentic data are used. Majority of people with literacy, balance number of ethnicity and majority of people with agricultural background has been interacted for data collection. The information collected form primary and secondary source of data are presented and analyzed descriptively, analytically and explanatorily. 


\section{Finding and Result Discussion}

\section{Impacts of Tourism}

The tourism industry generates substantial economic benefits to both host and guest countries. Especially in developing countries, one of the primary motivations for a country to promote itself as a tourism destination is the expected economic improvement. As with other impacts, this massive economic development brings along both positive and negative consequences (UNEP, 2003). Thesocio-economic impacts of tourism described as the effects on host communities from direct and indirect relations with tourists, and interaction with the tourism industry. The impacts arise when tourism brings about changes in value systems, behavior and thereby threatens indigenous identity. Furthermore, changes often occur in community structure, family relationships, collective traditional life styles, ceremonies and morality. But tourism can also generate positive impacts as it can serve as a supportive for foster pride in cultural traditions and help avoid urban relocation by creating local jobs. The tourists have different kinds of interest and intention while coming for tourism. The participant said that the some of the local peoples are supporting them to fulfill their negative and criminal interest like supply of marijuana, meat of wild animals, sell them wild animals' organs. These all demands are motivating to the local peoples for criminal activities.

Current roles of tourism to enhance incomes of local residents varied greatly. The hotels and restaurants generally buy and/or consume agriculture (like vegetables) and livestock products (like milk, meat) from local producers to serve their guests. It can boost incomes to the residents. However, current level of demands and consumption of these products at the local market was reported to be low. Besides, local hotels sometimes denied buying local products for their lower quality. It suggests that existing tourism business offer modest level of contribution to enhance incomes from agriculture and livestock.

The participants of group discussion opined that contribution of tourism to enhance family business and tourism related activities was higher. Tourism business enhances small family business by purchasing food and beverage items, snacks, maps and other souvenirs. Such businesses enhance the networking to build enterprising capacity of the family. Likewise, tourism based activities demand various services (interpreter, guide, information etc.) and development infrastructure which facilitate direct and indirect incomes to the tourism entrepreneurs and service providers. Therefore, incomes to the tourism operators rely solely on the range of tourism activities offered. Interestingly, incomes related to the remittances, pension and salary were independent of any tourism activities in the villages.

It is also revealed that contribution of tourism to the livelihood of local residents was recognized at the minimal level. It was partly attributed to the fact that most of the income derived from tourism was siphoned to the limited number of tourism entrepreneurs. Although the impacts of tourism to socioeconomic, environment and community development were discussed, it was hard to comprehend these benefits to boost incomes for livelihoods of local residents.

Further, tourism was perceived as an opportunity to the local community to enhance incomes. Tourism business can, directly or indirectly, generate/enhance various capitals towards achieving secured livelihood outcomes. However, the capability of local residents was inadequate to grasp such opportunity. Such capabilities are often circumscribed by various capital assets that the household can access and manipulate for productive outcomes. Such assets may be shared by community members (like road) or owned by the individual households (land, skills). The changes on the status of various livelihood assets can affect the level of incomes to the households in particular and community in general. Respondents perceived that national park and its resources is the major natural asset for promoting tourism in the community. However, accessibility to the national park is regulated by the local institutions and national policies. Increased restriction on entry essentially reduces the access to and satisfaction from the national park safari and other activities.

\section{Socio-Economic Impacts}

Physical infrastructure was perceived to be substantially increased in the community. Although tourism triggered the development of infrastructure like roads, bridges and hospitals, these were not necessarily specific to the tourism. These infrastructures have largely contributed towards the overall economic development. While majority of the respondents ( 86 percent) perceived substantial improvement in transportation, 38 percent of them stated marginal or negligible progress on other tourism focused facilities like sanitation and viewing towers. It indicated that the increased transportation and travel 


\section{6 | Journal of APF Command and Staff College}

facilities was not perceived to be directly linked to the tourism promotion until there are other facilities like information centers, eco-parks, viewing towers and trails to inform and engage visitors.

The tourism has affected financial assets and opportunities of the households in the community. For majority of respondents ( 74 percent), the tourism has enhanced markets for local products like milk, meat and vegetables. The agricultural producers were able to sell their products to the hotels and restaurants which could fetch better incomes to the households. In addition, there was common practice of membership in different types of saving and credit cooperatives and groups in the community. Such cooperatives have facilitated regular saving and increased access to the easy loan at lower interest rate. However, 66 percent of respondents perceived that memberships in such cooperative has increased only marginally or remained stable over last ten years.

Likewise, tourism activities were perceived to increase employment opportunities in the community. The employment types included manages, nature guides, waiters, fishing and other local clubs. The hotel entrepreneurs were the major employer. Currently, 123 individuals in Kasara and 263 in Meghauli were employed by different hotels. Most of the low level staffs were hired from local communities. It meant that most of the luxury hotels were owned and managed by the bigger investors from outside the community. The local communities operated smaller outlets for selling snacks and other souvenirs to the tourists. It indicates that the major part of the incomes accrued from tourism has been siphoned outside local economy.

Overall, tourism has direct impacts and contribution on the livelihood assets of people. It has enhanced the capacity of local communities to diversify economic activities in local communities. The skill and knowledge has increased the confidence to run different tourism and other production activities like tourist operators/guide, small outlets to serve causal demands. Likewise, environmental awareness among local communities has enhanced capacity to advocate towards nature tourism for its sustainability. Though tourism is itself sensitive to many factors, it can provide opportunities for stable incomes during the normal periods. The tourism has increased the interaction with park authorities and hotel entrepreneurs to promote local employment and development. Such development enhances production system in the community. In addition to national park, the buffer zone forest has appeared to receive tourists for sight-seeing and nature trekking. As the economic activities have increased, it has enhanced the culture of regular saving among the villagers which acts as financial security at the time of need. The tourism has catalyzed the development of other infrastructures like roads and public facilities. Such infrastructures can enhance economic activities for the alternative livelihoods. Therefore, the tourism can be considered as the important vehicle toward enhancing different livelihood assets in the communities.

Moreover, tourism can have long and short term impacts to the livelihoods opportunities of the people. It has direct impacts on livelihood of people. Though current rate of employment is low and latitude of tourism activities is limited, it has certainly increased the opportunities to the communities to go beyond the traditional mode of production for their livelihoods. With the increasing health concerns from commercialized products, the demands for organic products are likely to increase in near future. Local communities can produce and offer products on demands to the tourists through hotels and restaurants. The increasing trends of homestays can promote local products which, in turn, fetch better incomes to the host families. Such opportunities gradually enhance the enterprising capacity and employment leading to the secured livelihoods. Some other impacts are listed below:

The host communities seem to lose their local identity and values: Commercialization of local culture is possible when the host societies consider tourism as a business. Businesses are meant for profits, and the profits are ensured with visitors' satisfaction. To satisfy the visitors, the host societies prefer economic ways of providing facilities to meet the expectations of the visitors. The host societies focused on satisfying the visitors by providing desired souvenirs, food and drinks, and accommodation. The conventional local food drinks, and accommodation might not be exactly what visitors prefer in faith tourism. In order to satisfy the visitors, there can be some changes in food, drinks, and accommodation. For example, visitors are likely to buy souvenirs from local businesses. As the demand increases, local businesses can change the indigenous taste of souvenir products to be economical or in line with the new design.

Cultural clash is likely as a social impact in the host community: Kasara consist of Hindu majority villages. Based on religious belief, there are about 91 percent of Hindus and remaining are others (CBS, 2011) and the host societies may suffer a stress from the other religions of the tourist. People from other 
religions dislike the unusual behaviors of the tourist against culture and religion because there is a threat of change in religious belief. Cultural clashes can further arise through economic inequality, irritation from visitor's behavior, and job related issues. Culture and indigenous practices of host community may revitalize and some tome it may decline.

The social stress can lead to social disadvantages for host community: Peoples from the host societies can cause riots, vandalism, bullying to remove heritage items, and disrespect to the visitors. A conflict is possible from uses of scarce resources between the tourism industry and host societies.

Possible offence in the host Community: As the population grows, the crime rate increases. Economic inequality helps increase crime for valuable belongings and money with visitors. A large number of visitors with a big sum of money to spend and their expensive belongings such as cell phones, cameras, and gold jewelries motivate criminals for crimes. In the same time, criminals and drug dealers can come to host societies for their interests that are also a challenging social impact for host community.

Economic Impacts: In the focused group discussion collectively they said that the tourism industry plays a significant role in increasing financial activities in the host societies. Tourism industry has direct, indirect, and induced impacts to the economy. The direct impacts can be seen in commodities, industries, and sources of spending. Accommodation, transportation, entertainment, and attractions are major sectors in commodities impacts. Some of them argued that the flow of tourists determines the rate of occupancy of hotels. Hotel businesses are very close to tourism activities and create various types of jobs for skilled and unskilled people. Travel agents are the businesses that sell itinerary, tickets, and counsel the tourists for their comforts. Restaurant businesses depend on a flow of tourists in the host societies. A large number of local jobs are created in restaurant businesses trekking, guide, porters and language assistance which also contribute to the local society.

Foreign Currency Income: The responders said that the role of tourism as an important source of foreign currency and income has been well established the world over. In most of the developed as well as developing countries, tourism is an important source for maximizing foreign money earnings. This may be the single most important contribution of this industry. A major economic benefit in promoting the tourism industry has therefore, tended to be the earning of foreign currency. Tourism industry contributes a good amount of revenue to the government of a country from taxes and duties on things tourists use and buy.

Income and Employment: Tourism as a source of income is not easy to measure, at least with any degree of accuracy. This is because of the multiplier effect. The flow of money generated by tourist spending multiplies as it passes through various sections of the economy through the operation of the multiplier effect. The multiplier is an income concept and this mechanism has also been applied to tourism and in particular to tourist expenditure. The money paid by a tourist in, say paying his hotel bill is used by the hotel management to provide for the costs which it had incurred in meeting the demands of the visitor, e.g., such goods, and services as food, drink, furnishing, laundering, electricity, and entertainment. The recipients, in turn, use the money they have thus received to meet their financial commitments.

Business Effects: Another significant benefit from the tourism industry to the local community is that it provides impetus to the development of trade and business. Development of tourism creates demand for different goods and services which will help to promote domestic trade. Tourism is expected to promote sales of handicrafts, curios, souvenir and other products. Tourists are found to spend considerably in such items. According to a study made in Europe, it is estimated that tourists reserve about $33 \%$ of their money for on the spot purchases of national products.

Local Development: Similarly the economic implication of tourism may also manifest in its impact on the structure of local economics and on the regimes of production and distribution as well as trade. New employment and income opportunities, particularly in hospitality services and trade sectors can open up due to tourism. Specialization in the production of agricultural, horticultural and livestock products for the tourist market may be one distinct expression of the impact on the production regime. The provision of tourist infrastructures like road, water system, electricity, hospitals, schools, hotels, shops and other public utilities highly contributed to the overall development of the economy of locals. The provision of tourist road may cause access of local farmers to market centers and moreover, the growth of tourism is likely to benefit large landowners through the effect on land prices. 
Infrastructure Development: Development and improvement of infrastructure is another important benefit of tourism. The benefits from infrastructure investments, justified primarily for tourism airports, roads, communication, electricity supply, water supply and other public utilities. In addition to development of new infrastructure, the improvements in the existing infrastructure which are undertaken to attract tourists are also of crucial importance. These improvements may confer benefits upon the resident population by providing them with amenities which, hitherto, they have not been enjoyed.

International Understanding and Interaction: Tourism also helps to improve international understanding between different nations and among the people of these nations also. In fact, travelling widens the knowledge of people. Face to face meeting the people of different races and culture enables them to promote greater understanding of common problems. Tourists can play a vital role in international understanding and keeping peace in the world by developing social, cultural, economic as well as political understanding among the peoples of different nations and by way of bringing diverse people face to face. Tourism promotes friendship and goodwill between the visitors and the people of host countries. The interaction between different peoples belonging to different countries and societies practicing different lifestyles and speaking different languages come together to makes friends.

Economic Costs of Tourism: The economic impacts of tourism and tourism-related development consist broadly of benefits and costs. Many of the socio-economic impacts discussed above have both positive and negative dimensions. Employment opportunities will increase the further development of tourism industry and also supports for the livelihood of the peoples. Commitments to develop infrastructure (water systems, roads and waste disposal systems) may be advantageous to both tourists and local communities.

\section{Conclusion}

This study takes an effort to identify the major socio- economic impacts on community through wildlife tourism with special reference to Kasara, Chitwan. The study identified the both of negative and positive socio-economic impacts of tourism. Positive impacts of tourism are to increase jobs, quality of life for locals and an increase the living standards of peoples. Tourism also has the advantage of rebuilding and restoring historic sites and encouraging the revitalization of cultures. Sometime tourism may decline the culture. Tourism impacts on residence and residence impacts on tourism. While interacting between hosts and guest each other they exchange their culture among them. While interacting between host and guest, the local community accepts of copying tourists' culture, dress style and language. They interact with the tourists; mix with people from diverse backgrounds which create a cosmopolitan culture in the region. Among the equity, power, lifecycle, social exchange and social representation theory the socio-economic impacts of tourism are related with social exchange theory. As social negative impact, cultural invasion, offensive activities, changing living styles and behavior of the young, language, tradition, work and technology religion, dress patterns were founded. Tourism can deliver benefits to the individual households and community. For individual household, tourism can enhance skills and opportunities to adopt alternative livelihood strategies. It is entirely dependent on the types of accessible livelihood assets and capacity to utilize them for enhancing incomes. At community level, improved physical infrastructure and networking can stimulate development to boost incomes. However, there was growing concerns that tourism business is largely captured by external investors. Local residents were often employed for low paid jobs and the hotel owners were found indifferent towards the local development. As a result, major part of the tourism based income was siphoned off the village. Therefore, the notion that tourism business improves livelihood of local resident is illusive in the study area. For this, policies intervention should focus on generating and enhancing livelihood assets of local residents through training, soft loan and linking them to the tourism markets. Such policy provision can help local residents to grasp the emerging livelihood opportunities from tourism sector.

\section{References}

Bhattarai, K., Conway, D., \& Shrestha, N. (2005). Tourism, terrorism and turmoil in Nepal. Annals of Tourism Research, 32(3), 669-688.

Bhusal, N. P. (2007). Chitwan National Park: A prime destination of eco-tourism in Central Tarai Region, Nepal. The Third Pole: Journal of Geography Education, 5, 70-75.

Burns, P. M., \& Holden, A. (1995). Tourism: A new perspective. FT Prenticehall. 
Chitwan National Park (2013a). Government of Nepal, Department of National Park and Wildlife Conservation, Chitwan National Park 2013. Address: http://www.chitwannationalpark.gov.np/. Retrieved October18, 2013.

Cook, J. M. (2011). Valuing protected areas through contingent valuation: a case study of Chitwan National Park, Nepal. Toronto, Ontario, Canada: Tesis de grado para optarpor el título de MagísterenCienciasAplicadas, Wilfrid Laurier University.

Dixon, J. A., \& Sherman, P. B. (1990). Economics of Protected Areas: a New Look at Benefits and Costs. Island Press.

Gautam, B. P. (2011). Tourism and economic growth in Nepal. NRB Economic Review, 23(2), 18-30.

Hall, C. M. (2000). Tourism planning: Policies, processes, relationships. Prentice Hall, London.

Higginbottom, K. (2004). Wildlife tourism. Altona: Common Ground.

Kaiser, C., \& Helber, L. (1978). Tourism planning and development. CBI Publishing Inc.

Krapf, K. (1961). Cited in Smith, L. and Eadington, W. (eds)(1992). Tourism Alternatives: Potentials and Problems in the Development of Tourism.

Kunwar, R. R. (2002). Anthropology of tourism: A case study of Chitwan-Sauraha, Nepal. Egully. com.

Kunwar, R. R. (2017). Tourists and tourism. Revised and Enlarged Edition. Boudhnath Printers, Kathmandu.

Kunwar, R. R. (2017). What is Hospitality?. The Gaze: Journal of Tourism and Hospitality, 8, 55-115.

Leiper, N. (1979). The framework of tourism: Towards a definition of tourism, tourist, and the tourist industry. Annals of Tourism Research, 6(4), 390-407.

Lynch, P., Molz, J. G., Mcintosh, A., Lugosi, P., \& Lashley, C. (2011). Theorizing hospitality. Hospitality \& Society, 1(1), 3-24.

Mathieson, A., \& Wall, G. (1982). Tourism, economic, physical and social impacts. Longman.

Mishra, H. R. (1982). Balancing human needs and conservation in Nepal's Royal Chitwan Park. Ambio, 246251.

Murphy, K. J. (1985). Corporate performance and managerial remuneration: An empirical analysis. Journal of Accounting and Economics, 7(1-3), 11-42.

Nachamias, C. F., \& Nachamias, D. (2000). Research methods in the social sciences (5th ed.). ew York: St. Martin's Press.

Nayomi, G., \& Gnanapala, W. A. (2015). Socio-Economic Impacts on Local Community through Tourism Development with Special Reference to Heritance Kandalama. Tourism, Leisure and Global Change, 2(1), 57-73.

Park, N. J. M. C., \& Bardecki, M. J. (2016). The valuation of protected areas: tourists in Chitwan National Park, Nepal. In World Heritage Sites and Tourism (pp. 176-188). Routledge.

Pedersen, A. (2002). Managing tourism at world heritage sites. A Practical Manual for World Heritage Site Managers. ICOMOS.

Peters, J. A. (1964). Dictionary of herpetology (p. 392). New York: Hafner Publishing Company.

Roe, D. (1997). Take only photographs, leave only footprints: The environmental impacts of wildlife tourism (No. 10). lied.

Smith, S. L. (1988). Defining tourism a supply-side view. Annals of Tourism Research, 15(2), 179-190.

Wahab, S., \& Pigram, J. J. (1997). Policy considerations. Tourism, Development and Growth: The Challenge of Sustainability, 277.

Wikramanayake, E.D., Dinerstein, E., Robinson, J.G., Karanth, K.U., Rabinowitz, A., Olson, D., Mathew, T., Hedao, P., Connor, M., Hemley, G., Bolze, D. (1999). Where can tigers live in the future? A framework for identifying high-priority areas for the conservation of tigers in the wild. In: Seidensticker, J., Christie, S., Jackson, P. (eds.) Riding the Tiger. Tiger Conservation in Humandominated Landscapes, Cambridge University Press, Cambridge.

World Tourism Organization (WTO), (2000). Basic references on tourism statistics, Madrid, WTO.

World Tourism Organization. (2012). UNWTO tourism highlights 2012 edition. Madrid, Spain.

World Travel and Tourism Council, (2012). Travel and tourism economic impact 2012. London, WTTC. 